\title{
Acid Phosphatases from the Liver of Labeo rohita: Purification and Characterization
}

\author{
Aisha SiddiQua, ${ }^{a}$ Mamoona Rehmat,${ }^{a}$ Asma Saeed, ${ }^{b}$ Shazia Amin, ${ }^{a}$ Rubina Naz, ${ }^{a}$ Mehrin Sherazi,${ }^{a}$ \\ Gul Majeed KHAN, ${ }^{\mathrm{c}}$ and Ahmad SAEED ${ }^{*, a}$ \\ ${ }^{a}$ Department of Chemistry, Gomal University; ${ }^{b}$ Department of Biological Sciences, Gomal University; and ${ }^{c}$ Department \\ of Pharmaceutics, Faculty of Pharmacy, Gomal University; Dera Ismail Khan 29050, Pakistan. \\ Received October 8, 2007; accepted January 18, 2008; published online February 4, 2008
}

Low molecular weight acid phosphatase (LM-ACP) peak 2 (the isoenzyme corresponding to isoform 2, IF-2) from the liver of fish Rahu (Labeo rohita) was purified to homogeneity. 900 times purification resulted with specific activity of $35 \mathrm{U} / \mathrm{mg}$ of protein and recovery of $0.2 \%$. The enzyme was found homogeneous on sodium dodecyl sulphate polyacrylamide gel electrophoresis (SDS-PAGE). Molecular weight of 18 killo Daltons (kDa) was obtained. The peak 1 isoenzyme corresponding to isoform1 (IF-1) was partially purified about 160 times with specific activity of $7 \mathrm{U} / \mathrm{mg}$ of protein. Major protein band corresponding to $18 \mathrm{kDa}$ was seen along with other protein faint bands. High molecular weight acid phosphatase (HM-ACP) was also partially purified. The molecular weight was estimated to be a $100 \mathrm{kDa}$ by gel filtration on Sephadex G-100. LM-ACP isoenzymes and HM-ACP enzyme were studied for their substrate specificity, sensitivity to inhibitors or activators and other kinetic parameters. LM-ACP isoenzymes were not inhibited by tartrate and fluoride but were inhibited by sulfhydryl reagent whereas high molecular weight enzyme was strongly inhibited by fluoride and tartrate. Phosphate vanadate and molybdate inhibited both types of enzymes competitively, but their action was more pronounced in HM-ACP enzyme. LM-ACP was effectively activated by purine compounds whereas HM-ACP was not. LM-ACP showed strict substrate specificity while HM-ACP showed broad substrate specificity. The two types of acid phosphatases also differed in their rate of hydrolysis of $\alpha$-naphthyl phosphate and $\beta$-glyerophosphate.

Key words acid phosphatase; zinc-dependent acid phosphatase; purification; characterization

Acid phosphatases (EC 3.1.3.2) are widely distributed in nature and often occur in multiple forms differing in molecular sizes, localization within the cell, substrate specificity and sensitivity to inhibitors. ${ }^{1)}$ In animals its biological role is not yet clear but it is involved in many biological systems which are linked to energy metabolism, metabolic regulation and cellular signal transduction path ways. ${ }^{2)}$

Mammalian liver contains two acid phosphatase forms (molecular weight $90-107 \mathrm{kDa}$ and $14-30 \mathrm{kDa}$ ) and these can be separated by gel chromatography on Sephadex G$75 .^{3-6)}$ The effects of inhibitors, substrates and kinetic parameters also distinguish between the enzymes. ${ }^{7-9)}$ The acid phosphatase (molecular weight $107 \mathrm{kDa}$ ) purified from human liver to homogeneity had been extensively characterized. ${ }^{5,8)}$ The enzymes from liver of carp, catfish and frog had also been purified ${ }^{10-12)}$ and found to be glycoprotein in nature. Previously, low molecular weight acid phosphatases had been purified from human liver, ${ }^{9,13}$ bovine liver, ${ }^{3,14,15)}$ rat liver, ${ }^{16,17)}$ porcine liver ${ }^{18)}$ bovine heart, ${ }^{19,20)}$ brain, ${ }^{21)}$ human placenta $^{22)}$ and human erythrocytes. ${ }^{23)}$ In all cases, the enzymes had molecular weights ranging between $14-18 \mathrm{kDa}$.

Two distinct isoforms of low molecular weight acid phosphatase exist in rat liver ( $\mathrm{AcP} 1$ and $\mathrm{AcP} 2)$, human erythrocytes $\left(\mathrm{B}_{\text {fast }}\right.$ and $\left.\mathrm{B}_{\text {slow }}\right)$ and human placenta (HCPTP-A and HCPTP-B) and these have also been isolated, characterized and sequenced. ${ }^{17,24,25)}$ The AcP1, $\mathrm{B}_{\text {fast }}$ and HCPTP-A have been classified as IF-1 while AcP2, $\mathrm{B}_{\text {slow }}$, HCPTP-B, bovine heart PTPase and bovine liver PTPase as IF-2. IF-1 and IF-2 differ from each other in type specific sequence of the 40 73 regions, in substrate affinity and in the sensitivity to activators and inhibitors. ${ }^{26)}$

In our laboratory we have also purified and characterized these enzyme couples from chicken liver ${ }^{27)}$ and uromastix liver. ${ }^{28)}$ These differ in pyridoxal-5' $-\mathrm{PO}_{4}$ inhibition, cGMP activation and some kinetic parameters. Both isoenzyme couples possess phosphotyrosine protein phosphatase activity. None of all enzymes (LM-ACP and HM-ACP) need metal ion for their activity.

Another class of acid phosphatases called $\mathrm{Zn}^{++}$-dependent acid phosphatases, exist in two forms of different molecular weight. ${ }^{29,30)} \mathrm{Zn}^{++}$-dependent acid phosphatases have also been isolated and characterized in the liver of different vertebrates. $^{31)}$

This paper describes the purification and characterization of LM-ACP and HM-ACP from fish (Labeo rohita) liver and the resolution of the two low molecular weight isoenzymes (IF-1 and IF-2 types) by affinity chromatography on $p$ aminobenzyl phosphonic acid-agarose column.

\section{MATERIALS AND METHODS}

Materials L. rohita (common name Rohu) was captured from Indus river (N.W.F.P. Pakistan) and liver was excised immediately and stored at $4{ }^{\circ} \mathrm{C}$ for use. para-Nitrophenyl phosphate (pNPP), phenyl phosphate, flavin mononucleotide (FMN), phosphotyrosine and other substrates were purchased from Merk, Fluka and Sigma Chemical Co.; SDS molecular weight markers, Sephadex G-75 and Sephadex G-100 were supplied by Sigma. The reagents for SDS-PAGE were from Acros Chemical Co.; Aldrich and Sigma; CM-cellulose was obtained from Whatman Biosystem Ltd.; p-amino benzylphosphonic acid-agarose gel was purchased from Pierce Chemical Co.; all other reagents were of the highest purity commercially available.

Methods. Enzyme Assays Assay for acid phosphatase was performed at $37^{\circ} \mathrm{C}$ using pNPP as substrate, dissolved in 
$0.1 \mathrm{M}$ acetate buffer $\mathrm{pH} 5.5 .^{32)}$ The reaction was started by addition of enzyme solution in a final volume of $0.5 \mathrm{ml}$. After $5 \mathrm{~min}$, the reaction was stopped by adding $0.5-1.5 \mathrm{ml}$ of $0.1 \mathrm{M} \mathrm{KOH}$ and the absorbance of the liberated $p$-nitrophenol was read at $405 \mathrm{~nm}\left(\varepsilon_{405} 18000 \mathrm{M}^{-1} \mathrm{~cm}^{-1}\right) . \mathrm{Zn}^{++}$-dependent acid $p$-nitrophenyl phosphatase activity was determined as described by Panara ${ }^{29)}$ and Fujimoto et al. $^{30)}$ in acetate buffer pH 6.0 containing $5 \mathrm{~mm} \mathrm{ZnCl}_{2}$ and $10 \mathrm{~mm} \mathrm{NaF}$ as inhibitors of HM-ACP in order to exclude the activity of high molecular weight enzyme.

One unit of enzyme was defined as the amount of the enzyme that produces $1 \mu \mathrm{mol}$ of $p$-nitrophenol/min. Specific activity was expressed as enzyme units per mg of protein.

The effects of metal ions and some modifier substances on the enzyme activity were assayed as reported previously. ${ }^{33)}$ $K_{\mathrm{m}}$ values were determined by measuring the $p$-nitrophenol produced after incubation for an appropriate period at different concentrations of substrate ranging from 0.1 to $1.6 \mathrm{~mm}$ in absence and presence of one or two fixed concentrations of inhibitors. Lineweaver-Burk plots were used to arrive at the values of $K_{\mathrm{i}}$.

The enzyme activity for a number of other phosphorylated compounds was determined under above conditions by estimation of inorganic phosphate $\left(P_{\mathrm{i}}\right)$ liberation. The liberated $P_{\mathrm{i}}$ was determined by the method of Black and Jones. ${ }^{34)}$

$K_{\mathrm{m}}$ and $V_{\max }$ against various substrates were also determined by measuring the amount of $P_{\mathrm{i}}$ released after enzymic reaction at different concentrations of substrate, which was calculated, from the standard curve using $\mathrm{KH}_{2} \mathrm{PO}_{4}$ as standard.

Protein Determination Protein concentration was determined by the biuret method. For column effluents the relative protein concentration was estimated from the absorbance at $280 \mathrm{~nm}$.

Electrophoresis SDS-PAGE was carried out by the method of Laemmli ${ }^{35}$ ) under reduced and non-reduced conditions. The samples of acid phosphatase were prepared in sample buffer with and without reduction by $\beta$-mercaptoethanol and heated at $95^{\circ} \mathrm{C}$ for $5 \mathrm{~min}$. The enzyme purity was checked in $12 \%$ acrylamide mini-slab gel. After the run, the proteins in the gel were stained with coomassie blue and the molecular weight estimates were made using standard size marker proteins as indicated in the respective figure. The correlation coefficient of plot of $\log$ of the molecular weight versus mobility of protein band was 0.993 .

Gel Filtration and Apparent Molecular Weight Determination Fish liver extract was salted out with ammonium sulphate $(30-60 \%$ saturation) and placed on Sephadex G100 column $(1.8 \times 85 \mathrm{~cm})$, which was previously equilibrated and eluted with $0.01 \mathrm{M}$ acetate buffer $\mathrm{pH} 5.0$ containing $1 \mathrm{~mm}$ $\beta$-mercaptoethanol and $0.1 \mathrm{M} \mathrm{NaCl}$ at flow rate of $30 \mathrm{ml} / \mathrm{h}$. Fractions (about $3.5 \mathrm{ml}$ each) were collected for assays of protein and enzymes activities. Apparent molecular weights of HM-ACP and LM-ACP were estimated on a calibrated Sephadex G-100 column by a comparison of their elution volumes to those of standard proteins. The proteins used were bovine serum albumin, carbonic anhydrase, cytochrome $c$ and aprotinin.

Purification of Enzymes Low Molecular Weight Acid Phosphatase (LM-ACP): All operations were carried out at $4{ }^{\circ} \mathrm{C}$. LM-ACP isoenzymes were purified according to
Manao et al. $^{17)}$ and Saeed. ${ }^{27)}$

Fish liver was homogenized in a Waring blender for 2$3 \mathrm{~min}$ with $30 \mathrm{~s}$ intervals and 3 volumes of $0.3 \mathrm{M}$ acetate buffer $\mathrm{pH} 5.0$ containing $1 \mathrm{~mm}$ ethylenediamine tetra acetate (EDTA), $0.1 \mathrm{~mm}$ phenylmethylsulfonyl fluoride (PMSF) and $1 \mathrm{~mm} \beta$-mercaptoethanol was added, followed by stirring for $1 \mathrm{~h}$. The homogenate was centrifuged at $2740 \boldsymbol{g}$ for $30 \mathrm{~min}$. The supernatant was collected and pellet was discarded.

Solid ammonium sulphate was added to $30 \%$ saturation with gradual additions and constant stirring. After $0.5 \mathrm{~h}$, the mixture was centrifuged at $2740 \mathrm{~g}$ for $30 \mathrm{~min}$. The supernatant was brought to $60 \%$ saturation. The resulting mixture was stirred for $1-2 \mathrm{~h}$ and then centrifuged at $2740 \boldsymbol{g}$ for $1 \mathrm{~h}$. The precipitate, thus obtained was dissolved in reasonable amount of $0.01 \mathrm{~m}$ acetate buffer $\mathrm{pH} 5.1$ containing $1 \mathrm{~mm}$ EDTA, $0.1 \mathrm{~mm}$ PMSF and $1 \mathrm{~mm} \beta$-mercaptoethanol. The suspension was stirred for $1-2 \mathrm{~h}$ to extract the enzyme and again centrifuged at $10000 \mathrm{~g}$ for $1 \mathrm{~h}$. The clear supernatant was dialyzed against $10-121$ of the same buffer over $24 \mathrm{~h}$ with $2-3$ replacements of fresh buffer. The dialysate was centrifuged at $10000 \boldsymbol{g}$ for $1 \mathrm{~h}$ and supernatant was applied to a SP-Sephadex C-50 column $(6.5 \times 33 \mathrm{~cm})$ previously equilibrated with dialyzing buffer and column was washed with the same buffer.

During column washing the HM-ACP, lysosomal in origin, was eluted. The fractions containing HM-ACP were pooled. This enzyme constituted about $5-10 \%$ of the total enzyme activity and was considered as starting material for further purification of HM-ACP. After washing the column with buffer, the bound LM-ACP (cytosolic in nature) was eluted by $0.3 \mathrm{M}$ phosphate buffer $\mathrm{pH} 5.5$ containing $1 \mathrm{~mm}$ EDTA, $0.1 \mathrm{~mm}$ PMSF and $1 \mathrm{~mm} \beta$-mercaptoethanol (single step). The fractions containing reasonable activities were pooled together and the enzyme was precipitated by adding ammonium sulphate to $70 \%$ saturation. The precipitate was collected by centrifugation at $10000 \boldsymbol{g}$ for $1 \mathrm{~h}$ and was dissolved in suitable volume of acetate buffer $\mathrm{pH} 5.0$ containing $1 \mathrm{~mm}$ EDTA, $0.1 \mathrm{~mm}$ PMSF and $1 \mathrm{~mm} \beta$-mercaptoethanol. The enzyme solution was then placed on Sephadex G-75 column $(3.2 \times 85 \mathrm{~cm})$ that was equilibrated and eluted with above buffer containing $0.1 \mathrm{M} \mathrm{NaCl}$. The active fractions were pooled and concentrated by ultrafiltration using $\mathrm{YM}_{3}$ membrane at 40-psi pressure.

The enzyme after gel filtration was dialysed overnight against 11 of $0.1 \mathrm{M}$ citrate buffer $\mathrm{pH} 6.5$ containing $1 \mathrm{~mm}$ EDTA and $1 \mathrm{~mm}$ dithiothreitol (DTT). The sample was applied to a column $(1.0 \times 5 \mathrm{~cm})$ of $p$-aminobenzylphosphonic acid-agarose that was equilibrated with the same buffer. The column was washed extensively with buffer to eliminate unbound proteins. During the washing phase, a well-separated acid phosphatase peak1 (IF-1 type) was eluted. The pure enzyme (peak 2) corresponding to IF-2 was eluted by a 0 $0.1 \mathrm{M}$ sodium phosphate linear gradient in same buffer (total volume of $50 \mathrm{ml}$ ). The fractions containing enzymic activity were pooled separately and concentrated by ultrafiltration.

High Molecular Weight Acid Phosphatase (HM-ACP) and $\mathrm{Zn}^{++}$-Dependent Acid Phosphatase: Unbound acid phosphatase from SP-Sephadex C-50 column corresponding to $0.3 \mathrm{~kg}$ fish liver was precipitated by adding ammonium sulphate to $70 \%$ saturation and collected by centrifugation at $10000 \boldsymbol{g}$ for $1 \mathrm{~h}$. The precipitate was dissolved in about $32 \mathrm{ml}$ 
Table 1. Purification of LM-ACP from Fish Liver

\begin{tabular}{|c|c|c|c|c|c|c|}
\hline & $\begin{array}{l}\text { Volume } \\
\text { (ml) }\end{array}$ & $\begin{array}{l}\text { Total activity } \\
\text { (U) }\end{array}$ & $\begin{array}{l}\text { Total protein }{ }^{b)} \\
(\mathrm{mg})\end{array}$ & $\begin{array}{l}\text { Specific activity } \\
(\mathrm{U} / \mathrm{mg})\end{array}$ & $\begin{array}{l}\text { Purification } \\
\text { factor }\end{array}$ & $\begin{array}{c}\text { Recovery } \\
(\%)\end{array}$ \\
\hline Extract $^{a)}$ & 3890 & 3602 & 90050 & 0.04 & 1 & 100 \\
\hline $30-60 \%\left(\mathrm{NH}_{4}\right)_{2} \mathrm{SO}_{4}$ saturation & 550 & 1155 & 28875 & 0.04 & 1 & 32 \\
\hline SP-Sephadex C-50 & 32 & 105.28 & 169.6 & 0.62 & 15.5 & 2.9 \\
\hline Sephadex G-75 & 15 & 48.9 & 42 & 1.16 & 29.0 & 1.35 \\
\hline \multicolumn{7}{|l|}{ Affinity chromatography } \\
\hline Peak 1 & 19 & 1.25 & 0.19 & 6.58 & 164.5 & 0.033 \\
\hline Peak 2 & 13 & 6.06 & 0.17 & 35.6 & 890 & 0.16 \\
\hline
\end{tabular}

a) Starting from $1200 \mathrm{~g}$ of fish liver. b) Protein concentration was determined by Biuret method.

of $0.01 \mathrm{M}$ acetate buffer $\mathrm{pH} 5.0$ containing $1 \mathrm{~mm}$ EDTA and $1 \mathrm{~mm} \beta$-mercaptoethanol and applied in three batches to Sephadex G-100 $(2.4 \times 85 \mathrm{~cm})$ equilibrated with $0.01 \mathrm{M} \mathrm{ac}-$ etate buffer $\mathrm{pH}$ 5.0, $1 \mathrm{~mm}$ EDTA, $1 \mathrm{~mm} \beta$-mercaptoethanol and $0.1 \mathrm{M} \mathrm{NaCl}$ and eluted with the same buffer. Acid phosphatase and $\mathrm{Zn}^{++}$-dependent acid $p$-nitrophenyl phosphatase were eluted together and their activity peaks were not superimposable. The most active fractions were pooled and dialyzed against 51 of $0.01 \mathrm{M}$ acetate buffer $\mathrm{pH} 6.0$ containing $1 \mathrm{~mm}$ EDTA and $1 \mathrm{~mm} \beta$-mercaptoethanol. The dialyzed sample was applied to CM-Cellulose column $(2.5 \times 18 \mathrm{~cm})$ that was equilibrated with dialyzing buffer. The column was washed with same buffer until the absorbance at $280 \mathrm{~nm}$ was less than 0.1. Both acid phosphatase and $\mathrm{Zn}^{++}$-dependent acid $p$-nitorophenyl phosphatase activities were eluted with $0-0.5 \mathrm{M} \mathrm{NaCl}$ linear gradient in the same buffer (total volume of $400 \mathrm{ml}$ ). The active fractions were pooled, concentrated by ultrafiltration and used for further studies.

\section{RESULTS}

LM-ACP peak 2 (IF-2) was purified to homogeneity. The purification steps are presented in Table 1 and their elution profiles by various chromatographic techniques are shown in Figs. $1 \mathrm{~A}-$ C. $0.2 \mathrm{mg}$ of this isoenzyme was obtained. Ninehundred times purification was resulted with specific activity of $35 \mathrm{U} / \mathrm{mg}$ of total protein and recovery of $0.2 \%$. The homogeneity of the enzyme was checked on $12 \%$ SDS-PAGE. Single band was detected and molecular weight of $18 \mathrm{kDa}$ was obtained (Fig. 2). Similarly, LM-ACP peak 1 (IF-1) was partially purified about 160 times with specific activity of $7 \mathrm{U} / \mathrm{mg}$ of protein. The recovery was very small. The major protein band on SDS-PAGE corresponding to $18 \mathrm{kDa}$ was seen along with few faint protein bands of low and high molecular weights. The molecular weight of both isoenzymes obtained by SDS-PAGE and gel filtration (Fig. 3) showed the same value. Both isoenzymes were found to be monomeric proteins.

HM-ACP was partially purified from fish liver. The major purification steps are summarized in Table 2. The elution profiles are shown in Figs. 4A and B. The purification of acid phosphatase was achieved 12.5 fold with recovery of $2.6 \%$. The enzyme had a specific activity of $0.5 \mathrm{U} / \mathrm{mg}$ of protein. The molecular weight of native enzyme obtained by gel filtration on calibrated Sephadex G-100 column was $100 \mathrm{kDa}$ (Fig. 3). This value is similar to molecular weight reported for prostatic acid phosphatases, ${ }^{36,37)}$ acid phosphatase of Drosophila virilis ${ }^{38)}$ and that of rat $^{39)}$ and human liver. ${ }^{8)}$
These enzymes are all glycoproteins composed of identical or very similar subunits of molecular weights $50 \mathrm{kDa}$. The molecular weight of $\mathrm{Zn}^{++}$-dependent acid $p$-nitrophenyl phosphatase was estimated to be $110 \mathrm{kDa}$ on gel filtration. When fish liver extract was applied on Sephadex G-100, this enzyme was eluted slight earlier than the $100 \mathrm{kDa}$ acid phosphatase. On this basis, it can be concluded that liver also contains $\mathrm{Zn}^{++}$-dependent acid phosphatase enzyme having a molecular weight of $110 \mathrm{kDa}$.

Kinetic Properties $K_{\mathrm{m}}$ and $V_{\max }$ against various substrates are reported in Table 3 . The $K_{\mathrm{m}}$ values for peak 2 were two times higher than the $K_{\mathrm{m}}$ values of peak 1 except for phosphotyrosine where the $K_{\mathrm{m}}$ value for peak 2 was six times greater than that of peak 1 .

$V_{\max }$ values showed that FMN was as good substrate as pNPP and phenyl phosphate especially for peak 2. Taga and Van Etten ${ }^{9)}$ noted that FMN was hydrolysed with $V_{\max }$ three times larger at $\mathrm{pH} 5.0$ when compared to pNPP. High specificity for FMN in LM-ACP from Xenopus laevis ${ }^{40)}$ was also noted but the enzyme catalyses the hydrolysis of FMN at only $84 \%$ of the $V_{\max }$ for pNPP. Our finding was also consistent with that of Xenopus laevis. Phosphotyrosin was also hydrolysed at the rate exhibiting 62\% (peak 1) and 40\% (peak 2) of $V_{\max }$ for pNPP suggesting that the both isoenzymes may act as phosphotyrosine protein phosphatases (PTPases).

Substrate Specificity The relative hydrolytic rates on different phosphate esters are shown in Table 4. LM-ACP isoenzymes (peak 1 and peak 2) hydrolysed pNPP, phenyl phosphate, phosphotyrosin, FMN and $\beta$-naphthyl phosphate at significant rates. Other substrates like $\alpha$ - and $\beta$-glycerophosphates, nucleoside phosphates, sugar phosphates etc. were not hydrolysed to any significant extent. Thus, both isoenzymes showed very restricted substrate specificity. This result is comparable to other low molecular weight acid phosphatase isoenzymes (PTPases) isolated from bovine liver, ${ }^{32)}$ bovine heart, ${ }^{20)}$ bovine brain, ${ }^{21)}$ human placenta ${ }^{22)}$ and rat liver. ${ }^{17)}$ In contrast HM-ACP showed broad specificity. The hydrolysis rates indicate that pNPP; phenyl phosphate, $\alpha$ - and $\beta$-naphthyl phosphates and $\beta$-glycerophosphate are good substrates. Other substrates, including phosphoamino acids, nucleoside phosphates and sugar phosphates were hydrolysed at reasonable rates. However, LM-ACP and HM-ACP can also be distinguished from one another by their rates of hydrolysis of $\alpha$-naphthyl phosphate and $\beta$-glycerophosphate. HM-ACP hydrolysed these two substrates much more efficiently whereas LM-ACP hydrolyzes these at negligible rates. These results had good agreement with that obtained from rat liver, ${ }^{39}$ rabbit kidney, ${ }^{41)}$ bovine kidney ${ }^{1)}$ 

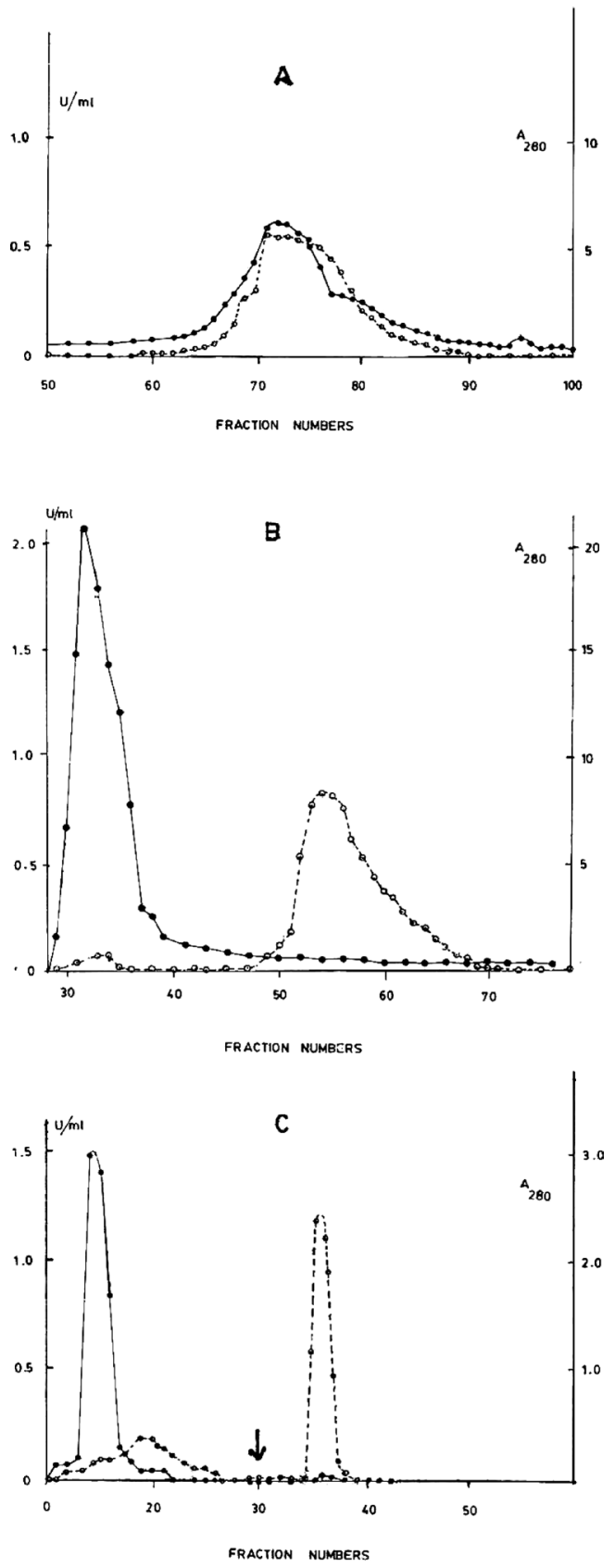

Fig. 1. (A) SP-Sephadex C-50 Chromatography

The sample was eluted from the column with flow rate of $200 \mathrm{ml} / \mathrm{h}$ and $20 \mathrm{ml}$ fractions were collected.

(B) Elution Profile from a Sephadex G-75

Column with a flow rate of $50 \mathrm{ml} / \mathrm{h}$ and $6 \mathrm{ml}$ fractions were collected.

(C) Affinity Chromatography on $p$-Aminobenzyl Phosphonic AcidAgarose Column

Flow rate, $15 \mathrm{ml} / \mathrm{h} ; 1 \mathrm{ml}$ fractions were collected. The arrow indicates the start of $P_{\mathrm{i}}$ gradient. Ordinates: protein at $280 \mathrm{~nm}(\bullet-\bullet)$; acid phosphatase activity, $\mathrm{U} / \mathrm{ml}$ (O- - O).

and human liver. ${ }^{8)}$

Effect of Purine and Pyrimidine Bases Purine compounds are known to activate low molecular weight acid phosphatases. ${ }^{16)}$ Their effects on both isoenzymes are shown in Table 5. Peak 2 isoenzyme was effectively activated by purine compunds. Guanosine was the most effective activator, followed by 6-ethylmercaptopurine and cGMP (2.5-3 fold activations). Guanosine was found better activator than

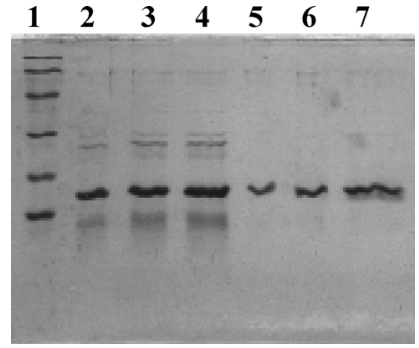

Fig. 2. SDS-Polyacrylamide Gel Electrophoresis of LM-ACP Peak 1 and Peak 2 Isoenzymes

Lane 1: the standard proteins used from top to bottom were rabbit muscle phosphorylase $(\mathrm{MW}=97400)$, bovine serum albumin $(66200)$, oval albumin $(42699)$, bovine trypsin inhibitor (31000), soybean inhibitor (21500), egg white lysozyme (14400). Lane 2, 3 and 4 : increasing amount of acid phosphatase peak 1 isoenzyme $(4,10,15 \mu \mathrm{l})$. Lane 5, 6 and 7: increasing amount of acid phosphatase peak 2 isoenzyme $(2,5,10 \mu \mathrm{l})$.

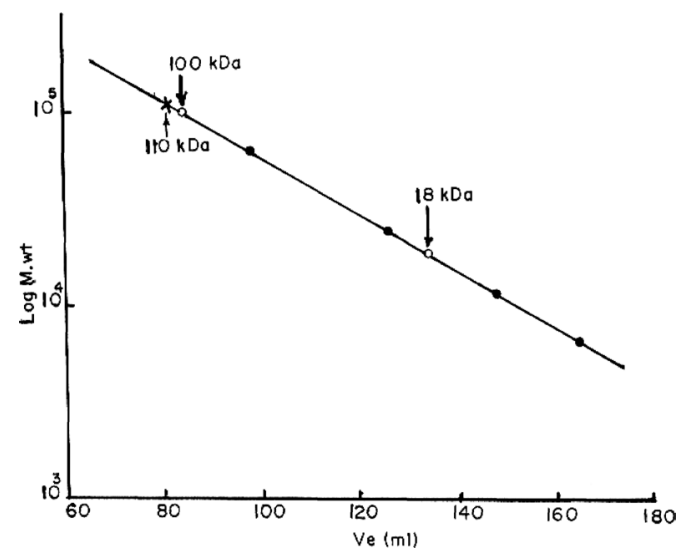

Fig. 3. Estimation of Molecular Weight of Acid Phosphatases on Sephadex G-100 Column

Three to five milligrams of each protein in about $3-4 \mathrm{ml}$ of buffer was applied onto the column and eluted as described in material and methods. Blue dextrin 2000 (average $\left.M 2 \times 10^{6}\right)$ was used to measure void volume $(V)$ of the column and elution volume $\left(V_{\mathrm{e}}\right)$ was determined from the absorbance at $280 \mathrm{~nm}$ for standard proteins $(\bullet)$ or by assay of enzyme activity at $405 \mathrm{~nm}$ for the samples. Bovine serum albumin $\left(M_{\mathrm{r}}\right.$ $66000), V_{\mathrm{e}} 98 \mathrm{ml}$; carbonic anhydrase $\left(M_{\mathrm{r}} 29000\right), V_{\mathrm{e}} 126 \mathrm{ml}$; cytochrome $c\left(M_{\mathrm{r}} 12400\right)$, $V_{\mathrm{e}} 148 \mathrm{ml}$; aprotinin $\left(M_{\mathrm{r}} 6500\right), V_{\mathrm{e}} 165 \mathrm{ml}$; LM-ACP $(\bigcirc), V_{\mathrm{e}} 134 \mathrm{ml}$; HM-ACP $(\bigcirc), V_{\mathrm{e}}$ $84 \mathrm{ml} ; \mathrm{Zn}^{++}$-dependent acid $p$-nitrophenyl phosphatase $(\times), V_{\mathrm{e}} 80 \mathrm{ml} ; V_{\mathrm{o}} 72 \mathrm{ml}$.

guanine. On the other hand, peak 1 isoenzyme was not activated by purine compounds, but was inhibited by adenine or guanine. The effects of pyrimidine nucleotides on both isoenzyme activities were not observed. These results are more or less similar to those of rat liver enzymes. ${ }^{16,17,27,42)}$ The increase in rate produced by purines is structure specific. At least substitution at 6 position of purine nucleus is essential for large rate enhancement. ${ }^{43)}$ 6-Ethylmercaptopurine is a good example in this case and caused high activation. Conversely, the phosphorylation of purine nucleoside leads to a progressive decrease in the extent of activation. AMP caused more activation than ADP whereas ATP resulted in a complete loss of activation (Table 5). The variation in the extent of activation by changes in the purine nucleus and by phosphorylation of the nucleoside suggest the existence of a specific site on the enzyme capable of binding the purine. This binding, occurring after the formation of the enzyme substrate complex results in an enhanced catalytic activity through a step that leads to the hydrolysis of covalent phosphoenzyme intermediate formed during the catalytic 
Table 2. Purification of HM-ACP from Fish Liver

\begin{tabular}{lcccccc}
\hline \hline & $\begin{array}{c}\text { Volume } \\
(\mathrm{ml})\end{array}$ & $\begin{array}{c}\text { Total activity } \\
(\mathrm{U})\end{array}$ & $\begin{array}{c}\text { Total protein } \\
(\mathrm{mg})\end{array}$ & $\begin{array}{c}\text { Specific activity } \\
(\mathrm{U} / \mathrm{mg})\end{array}$ & $\begin{array}{c}\text { Purification } \\
\text { factor }\end{array}$ & $\begin{array}{c}\text { Recovery } \\
(\%)\end{array}$ \\
\hline SP-Sephadex C-50 & 32 & 51.97 & 1280 & 0.04 & 1.33 & $5.7^{b)}$ \\
Sephadex G-100 & 127 & 34.5 & 469.9 & 0.073 & 2.44 & 3.0 \\
C-M cellulose & 7 & 29.4 & 58.8 & 0.5 & 12.5 & 2.6 \\
\hline
\end{tabular}

a) Non-bound activity fraction from SP Sephadex C-50 column. b) Recovery of $5.7 \%$ with respect to extract from $0.3 \mathrm{~kg}$ (refer to Table 1 ).
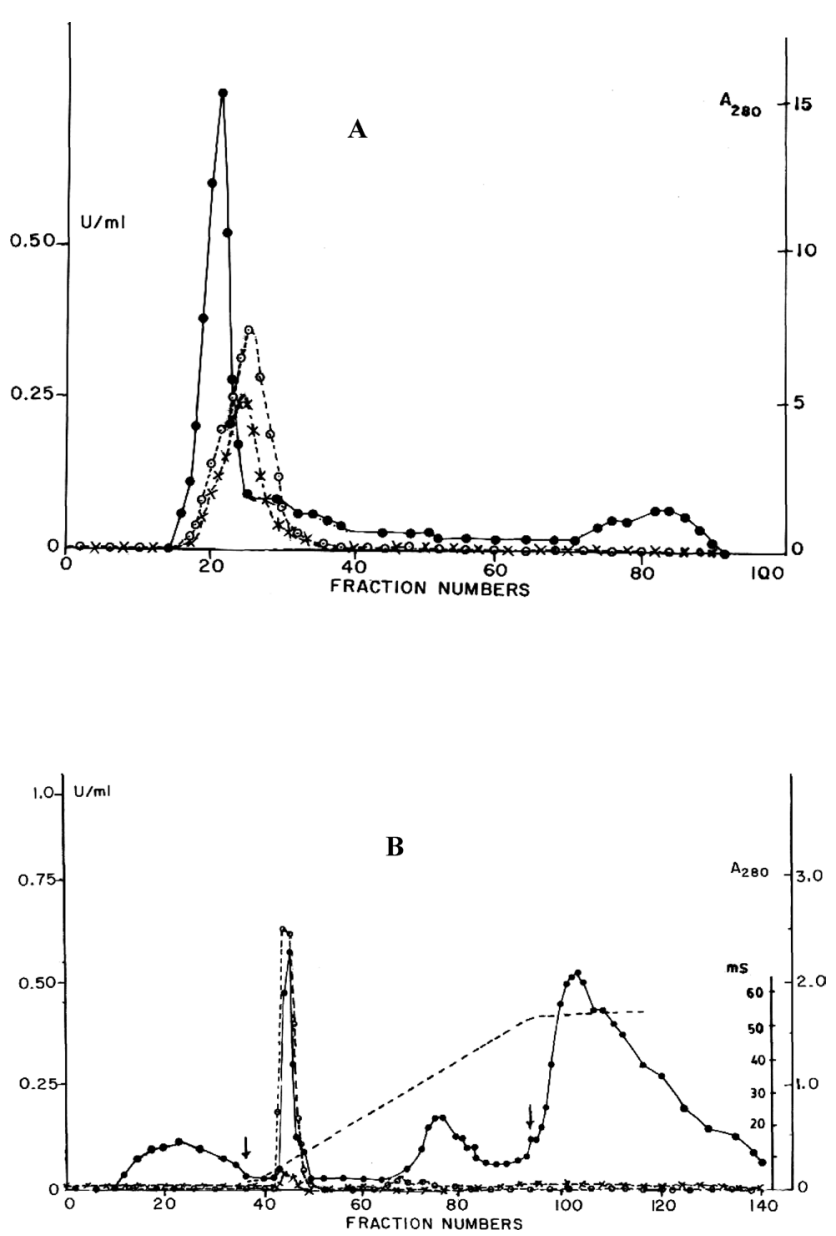

Fig. 4. (A) Gel Chromatography on Sephadex G-100

Sample applied was $10 \mathrm{ml}$; fractions of $5 \mathrm{ml}$ were collected at flow rate of $30 \mathrm{ml} / \mathrm{h}$.

(B) Elution Profile from CM-Cellulose Column with Flow Rate of $40 \mathrm{ml} / \mathrm{h}$ and 5-6 $\mathrm{ml}$ Fractions were Collected

The arrows indicate the start of linear salt gradient and single step elution with $0.5 \mathrm{M}$ $\mathrm{NaCl}$ in buffer respectively. Ordinates: Protein at $280 \mathrm{~nm}(-\bullet)$; acid phosphatase activity, $\mathrm{U} / \mathrm{ml}(\bigcirc---\bigcirc)$; Zn-dependent acid $p$-nitrophenyl phosphatase, $\mathrm{U} / \mathrm{ml}\left(\times--_{-} \times\right)$.

Table 3. The Kinetic Parameters for LM-ACP Isoenzymes from Fish Liver

\begin{tabular}{lcclcc}
\hline \hline \multirow{2}{*}{ Substrate } & \multicolumn{2}{c}{ Peak 1 isoenzyme } & & \multicolumn{2}{c}{ Peak 2 isoenzyme } \\
\cline { 2 - 3 } \cline { 5 - 6 } & $\begin{array}{c}K_{\mathrm{m}} \\
(\mathrm{mM})\end{array}$ & $\begin{array}{c}V_{\max } \\
\left(\mu \mathrm{mol} \mathrm{min}^{-1} \mathrm{mg}^{-1}\right)\end{array}$ & $\begin{array}{c}K_{\mathrm{m}} \\
(\mathrm{mM})\end{array}$ & $\begin{array}{c}V_{\max } \\
\left(\mu \mathrm{mol} \mathrm{min}^{-1} \mathrm{mg}^{-1}\right)\end{array}$ \\
\hline pNPP & 0.11 & 9.3 & & 0.23 & 38.7 \\
Phenyl phosphate & 0.16 & 7.6 & & 0.31 & 32.1 \\
Phosphotyrosine & 0.18 & 5.8 & & 1.1 & 15.4 \\
FMN & 0.20 & 8.2 & & 0.41 & 37.5 \\
\hline
\end{tabular}

Enzyme assays were carried out at $37^{\circ} \mathrm{C}$ and $\mathrm{pH}$ 5.5. The assay mixture contained $0.1 \mathrm{~m}$ acetate buffer, different concentrations of substrate ranging from 0.125 to $4 \mathrm{~mm}$ and the enzyme in a total volume of $0.5 \mathrm{ml}$. After incubation for $5 \mathrm{~min}$, the reaction was quenched by addition of $0.2 \mathrm{ml}$ of $10 \%$ TCA and the amount of inorganic phosphate released was determined by Black and Jones as described earlier.
Table 4. Substrate Specificity of LM-ACP and HM-ACP from Fish Liver

\begin{tabular}{lrrr}
\hline \hline \multirow{2}{*}{ Substrates } & \multicolumn{2}{c}{ LM-ACP } & \\
\cline { 2 - 3 } & $\begin{array}{c}\text { Peak } 1 \\
\text { isoenzyme }\end{array}$ & $\begin{array}{c}\text { Peak } 2 \\
\text { isoenzyme }\end{array}$ & \\
\hline pNPP & 100 & 100 & 100 \\
Phenyl phosphate & 87 & 79 & 89 \\
Phosphotyrosine & 73 & 35 & 24 \\
FMN & 91 & 98 & 45 \\
$\alpha$-Naphthyl phosphate & 3 & 8 & 88 \\
$\beta$-Napthyl phosphate & 81 & 70 & 116 \\
$\alpha$-Glycerophosphate & 15 & 13 & 19 \\
$\beta$-Glycerophosphate & 2 & 8 & 70 \\
Adenosine triphosphate & 0 & 0 & 25 \\
Adenosine monophosphate & 6 & 5 & 50 \\
Guanosine monophosphate & 1 & 3 & 32 \\
Cytidine monophosphate & 0 & 1 & 47 \\
Uridine monophosphate & 0 & - & 41 \\
Glucose-6-phosphate & 3 & 8 & 14 \\
Glucose-1-phosphate & 0 & 4 & 13 \\
Phosphoserine & 3 & 0 & 5 \\
Phosphothreonine & 1 & 0 & 9 \\
& & & \\
\hline
\end{tabular}

The incubation mixture consisted of $0.1 \mathrm{~m}$ acetate buffer $\mathrm{pH} 5.5,4 \mathrm{~mm}$ substrate and reasonable amount of enzyme in a final volume of $0.5 \mathrm{ml}$. After incubation at $37^{\circ} \mathrm{C}$ for $6-10 \mathrm{~min}$, the reaction was stopped by adding $0.2 \mathrm{ml}$ of $10 \%$ TCA and liberated inorganic phosphate was estimated by Black and Jones method. The enzyme activity was expressed as a percent of that of the same enzyme towards $p$-nitrophenyl phosphate as 100.

Table 5. Effect of Purine and Pyrimidine Compounds on the Acid Phosphatase Isoenzyme Activities

\begin{tabular}{lcc}
\hline \hline \multicolumn{1}{c}{$\begin{array}{c}\text { Purine/pyrimidine compounds } \\
(1 \mathrm{~mm})\end{array}$} & $\begin{array}{c}\text { Peak } 1 \text { isoenzyme } \\
\text { Activity }(\%)\end{array}$ & $\begin{array}{c}\text { Peak } 2 \text { isoenzyme } \\
\text { Activity }(\%)\end{array}$ \\
\hline $\mathrm{H}_{2} \mathrm{O}$ & 100 & 100 \\
Adenine & 76 & 194 \\
Guanine & 84 & 107 \\
Adenosine & 93 & 134 \\
Guanosine & 96 & 299 \\
6-Ethylmerceptopurine & 108 & 281 \\
cAMP & 106 & 126 \\
cGMP & 106 & 250 \\
GMP & 104 & 168 \\
AMP & 104 & 162 \\
ADP & 99 & 118 \\
ATP & 95 & 100 \\
CMP & 98 & 98 \\
UMP & 92 & 96 \\
\end{tabular}

The activity was determined by incubating the enzyme in a final mixture volume of $1 \mathrm{ml}$ containing $4 \mathrm{~mm}$-nitrophenyl phosphate, $0.1 \mathrm{M}$ acetate buffer $\mathrm{pH} 5.5$ in the presence and absence of the indicated additions. After $5 \mathrm{~min}$ incubation at $37^{\circ} \mathrm{C}$, the reaction was stopped by the addition of $1 \mathrm{ml}$ of $0.1 \mathrm{~N} \mathrm{KOH}$ and the absorbance at $405 \mathrm{~nm}$ was measured. The control activity without purine/pyrimidine compound was taken as $100 \%$ and the other activities were expressed as a percentage of this activity. Values are the means of triplicate determination. 
Table 6. The Competitive Inhibition Constants of Acid Phosphatases

\begin{tabular}{lccc}
\hline \hline \multirow{2}{*}{ Compounds } & \multicolumn{2}{c}{ LM-ACP } & \\
\cline { 2 - 3 } & $\begin{array}{c}\text { Peak 1 } \\
\text { isoenzyme }\end{array}$ & $\begin{array}{c}\text { Peak 2 } \\
\text { isoenzyme }\end{array}$ & \\
& & & \\
\hline Inorganic phosphate & $2.7 \mathrm{~mm}$ & $1.4 \mathrm{~mm}$ & $1.5 \mathrm{~mm}$ \\
Tartrate & $\mathrm{N} . \mathrm{D}$ & $\mathrm{N} . \mathrm{D}$ & $2.4 \mu \mathrm{M}$ \\
Vanadate & $138 \mu \mathrm{M}$ & $25 \mu \mathrm{M}$ & $0.7 \mu \mathrm{M}$ \\
Molybdate & $200 \mu \mathrm{M}$ & $80 \mu \mathrm{M}$ & $0.9 \mu \mathrm{M}$ \\
Pyridoxal-5'-PO & $208 \mu \mathrm{M}$ & $20 \mu \mathrm{M}$ & N.D \\
Pyridoxalamine-5'-PO & $17 \mathrm{~mm}$ & $13 \mathrm{~mm}$ & N.D \\
Pyridoxal & No inhibition & & N.D \\
\hline
\end{tabular}

$K_{\mathrm{m}}$ and $K_{\mathrm{i}}$ were determined by Lineweaver-Burk plots, employing linear regression method. Each value is the mean value of three determinations. Standard deviations do not exceed $10 \%$ of the mean valued. N.D; not determined.

process. $^{44,45)}$ The difference in peak 1 and peak 2 isoenzymes sensitivities to cGMP and very different peak 2 isoenzyme activation by cGMP and cAMP, suggests that these isoenzymes are regulated differently in the cell as already discussed in rat liver AcP 1 and AcP 2 isoenzymes by Ramponi and Stefani. ${ }^{45}$

Inhibition HM-ACP and LM-ACP differ not only in molecular weight and substrate specificity but also in sensitivity to inhibitors. HM-ACP was inhibited by fluorid and tartrate while LM-ACP isoenzymes were found to be insensitive to these known inhibitors as found in human liver enzymes. ${ }^{89}$ Formaldehyde and $p$-hydroxymercuri-benzoates, a reagent of sulfhydryl groups, showed inhibitions to LM-ACP as observed in enzymes of human placenta ${ }^{46}$ and bovin brain $^{47)}$ but slight inhibition was exhibited by HM-ACP enzyme. Both molecular forms were deactivated by $\mathrm{Cu}^{++}$and $\mathrm{Hg}^{++} . \mathrm{Zn}^{++}$ions were also found as an inhibitor. EDTA and Triton X-100 had no effect on both molecular forms of acid phosphatases. These results are in accord with the finding of Panara. ${ }^{29)}$ Phosphate, vanadate and molybdate inhibited both enzymes but their inhibitory action was more pronounced in HM-ACP. Their competitive inhibition constants are presented in Table 6. Peak 2 isoenzyme was more sensitive to these inhibitors than peak1 isoenzyme. The same results were found in rat liver. ${ }^{16)}$ Further peak 2 isoenzyme had high affinity for pyridoxal-5'-phosphate while peak1 isoenzyme had low affinity for it. Moreover, pyridoxamine- 5 ' -phosphate inhibited both isoenzymes poorly and pyridoxal did not inhibit at all. This suggests that strong binding of pyridoxal-5' phosphate to the active site is mediated through double interaction of two functional groups in the pyridoxal- $5^{\prime}$-phosphate $\left(\mathrm{PO}_{4}\right.$ ester bond and $-\mathrm{CHO}$ group) with both phosphate ion binding site and primary amino group at or near the active site.

Effect of Modifiers The effect of acetone, ethanol, methanol, glycerol and ethylene glycol on the activity of acid phosphatases with pNPP as a substrate was determined. LMACP (but not HM-ACP) was stimulated in the presence of these modifiers. Acetone, methanol and glycerol at $10 \%$ concentration caused almost two-fold increase in the enzyme activity. Ethanol and ethylene glycol were shown to be least activators. Such activations had been reported in many other LM-ACP. ${ }^{9,16,20,43)}$ The enzyme activation observed in the presence of glycerol or ethylene glycol was explained by the trans-phosphorylation reaction that competes with hydrolytic reaction of a phosphorylated enzyme intermediate ${ }^{20,28,43)}$ that reflects a phosphotransferase activity in LM-ACP only.

\section{DISCUSSION}

The data presented in this paper enabled us to extend our comparative studies on fish liver acid phosphatase by including $\mathrm{Zn}^{++}$dependent acid phosphatase. From fish liver, we isolated two types of acid phosphatases belonging to different molecular weight classes, low molecular weight acid phosphatase $(18 \mathrm{kDa})$ and high molecular weight acid phosphatase $(100 \mathrm{kDa})$. Our results of low molecular acid phosphatase isoenzymes are consistent with those of rat liver, ${ }^{16,17)}$ bovine brain, ${ }^{21)}$ chicken liver, ${ }^{27)}$ uromastix liver ${ }^{28)}$ and chicken heart $^{48}$ ) from which two forms of low molecular weight acid phosphatase isoenzymes have been isolated corresponding to IF1 and IF2 types. ${ }^{26,45)}$

Two low molecular weight acid phosphatases from fish liver have been purified by following the protocol of Manao et $a l .{ }^{17)}$ based on $\left(\mathrm{NH}_{4}\right)_{2} \mathrm{SO}_{4}$ precipitation, SP-Sephadex C50 chromatography, gel filtration on Sephadex G-75 and affinity chromatography on $p$-aminobenzyl phosphonic acid derivative of agarose column which was found to be critical for enzyme homogeneity as well as for resolution into two isoenzymes. This affinity gel was also successfully used for the purification of human erythrocytes low molecular weight acid phosphatase ${ }^{49}$ ) and other low molecular weight acid phosphatases from bovine brain, ${ }^{21)}$ rat liver, ${ }^{17)}$ chicken liver ${ }^{27)}$ and chicken heart ${ }^{48)}$ that are said to be pure enzymes, homogeneous with molecular weight of $18 \mathrm{kDa}$.

A total of $0.4 \mathrm{mg}$ of both isoenzymes was obtained from $1 \mathrm{~kg}$ with recovery of $0.2 \%$. Since the amount of the low molecular weight acid phosphatases is $15-20 \%$ of the total acid phosphatase activity present in the extract, the actual yield became $1.0 \%$ and purification factor was as high as 900 fold which was more or less similar to that of other low molecular weight acid phosphatases isolated from rat liver, uromastix liver and chicken liver but less than that of enzymes which were purified 5000 and 5700 fold from bovine brain ${ }^{21)}$ and bovine heart ${ }^{20)}$ respectively. Peak 1 isoenzyme showed specific activity of $6.5 \mathrm{U} / \mathrm{mg}$ of protein while peak 2 had specific activity of $35 \mathrm{U} / \mathrm{mg}$ which had smaller values than that of isoenzymes Apase A and Apase $\mathrm{B}^{16)}$ or AcP1 and AcP2 ${ }^{17}$ ) from rat liver, PTPase A and PTPase B from chicken liver and peak I and peak II from uromastix liver.

The enzymes were found homogenous as tested by SDSPAGE and had molecular weight of $18 \mathrm{kDa}$. The electrophoretic mobility was the same for both reduced and nonreduced enzymes indicating that that these isoenzymes were monomeric protein as reported in other small acid phosphatases. Small acid phosphatases having apparent molecular weights of $14-23 \mathrm{kDa}$ have been purified from human liver, ${ }^{9)}$ bovine liver ${ }^{3,15)}$ and heart. ${ }^{19)}$

Two isoenzymes differ in kinetic parameters, sensitivity to inhibitors and purine activation. As observed (Table 6) vanadate and molybdate were more potential inhibitors than phosphate. These results are consistent with related observations ${ }^{19,22)}$ that low molecular weight acid phosphatases possessing phosphotyrosin protein phosphatase activity were strongly inhibited by orthovanadate or molybdate in the micromolar concentration range. 
This and previous findings on different sensitivity to activators or inhibitors suggest that the two isoenzymes expressed in the same tissue and originated from single gene through alternative spacing mechanism, have a different function in the cell.

Non-bound HM-ACP from SP-Sephadex C-50 column was subjected to gel filtration on Sephadex G-100 followed by CM-Cellulose chromatography. Through this purification scheme, we obtained HM-ACP in partially purified form to study biochemical and kinetic properties. The molecular weight obtained by gel filtration was found to be $100 \mathrm{kDa}$. Nearly all of the known mammalian acid phosphatases are heterogeneous glycoproteins. ${ }^{50)}$ Acid phosphatases from liver of carp (122 kDa), catfish, frog $(140 \mathrm{kDa})$ and chicken $(102 \mathrm{kDa})$ are also glycoproteins. ${ }^{10,12,50)}$ The enzyme from fish liver might be glycoprotein but its purification by affinity chromatography on Con A column failed which may exhibit structures weakening their Con A binding abilities with carbohydrate chains.

Acknowledgements This work was supported in part by grant from Pakistan Science Foundation project No.R\&D/F.GU/Chem. (173) and HEC Indigenous $5000 \mathrm{Ph} . \mathrm{D}$ Fellowship Program Batch II, No.17-5-2 (PS 2-120)/ $\mathrm{HEC} / \mathrm{Sch} / 2004$

\section{REFERENCES}

1) Fujimoto S., Urata Y., Nakagawa T., Ohara A., J. Biochem. (Tokyo), 96, 1079-1088 (1984).

2) Shan J., Dissertation, Research Center for Molecular Endocrinology, Faculty of Medicine, University of Oulu, Oulu, Finland, 2002, p. 15.

3) Heinrikson R. L., J. Biol. Chem., 244, 299-307 (1969).

4) Campbell H. D., Dudman N. B. P., Zerner B., FEBS Lett., 31, 123 126 (1973).

5) Rehkop D. M., Van Etten R. L., Hoppe Seyler's Z. Physiol. Chem., 356, 1775-1782 (1975).

6) De Araujo P. S., Mies V., Miranda O., Biochim. Biophys. Acta, 452, 121-130 (1976)

7) Baldijao C. E. M., Guija E., Bittencourt H. M. S., Chaimovich H., Biochim. Biophys. Acta, 391, 316-325 (1975).

8) Saini M. S., Van Etten R. L., Arch. Biochem. Biophys., 191, 613-624 (1978).

9) Taga E. M., Van Etten R. L., Arch. Biochem. Biophys., 214, 505-515 (1982).

10) Janska H., Kubicz A., Comp. Biochem. Physiol., 82B, 563-567 (1985).

11) Janska H., Kubicz A., Bem M., Van Etten R. L., Comp. Biochem. Physiol., 85B, 753-758 (1986).

12) Kubicz A., Szalewicz A., Int. J. Biochem., 25, 1957-1961 (1993).

13) Laidler P. M., Taga E. M., Van Etten R. L., Arch. Biochem. Biophys., 216, 512-521 (1982).

14) Ramponi G., Cappugi G., Manao G., Camici G., 26th Natl. Meet. Ital. Biochem. Soc., 1980, p. 167.

15) Lawrence G. L., Van Etten R. L., Arch. Biochem. Biophys., 206, 122
$131(1981)$

16) Fujimoto S., Murakami K., Ishikawa A., Himi K., Ohara A., Chem. Pharm. Bull., 36, 3020-3026 (1988).

17) Manao G., Pazzagli L., Cirri P., Caselli A., Camici G., Cappugi G., Saeed A., Ramponi G., J. Prot. Chem., 3, 333-345 (1992).

18) Caselli A., Pazzagli L., Paoli P., Manao G., Camici G., Cappugi G., Ramponi G., J. Prot. Chem., 13, $107-115$ (1994).

19) Chernoff J., Li H. C., Arch. Biochem. Biophys., 240, 135-145 (1985).

20) Zhang Z. Y., Van Etten R. L., Arch. Biochem. Biophys., 282, 39-49 (1990).

21) Saeed A., Tremori E., Manao G., Camici G., Cappugi G., Ramponi G., Physiol. Chem. Phys. Med. NMR, 22, 81-94 (1990).

22) Waheed A., Laidler P. M., Wo Y. Y. P., Van Etten R. L., Biochemistry, 27, 4265-4273 (1988).

23) Dissing J., Svensmark O., Biochim. Biophys. Acta, 1041, 232-242 (1990).

24) Dissing J., Johnsen A. H., Sensabaugh G. F., J. Biol. Chem., 26 20619-20625 (1991).

25) Wo Y. Y. P., Zhou M. M., Stevis P., Davis J. P., Zhang Z. Y., Van Etten R. L., Biochemistry, 31, 1712-1721 (1992).

26) Ramponi G., Stefani M., Int. J. Biochem. Cell Biol., 29, 279-292 (1997).

27) Saeed A., Jour. Chem. Soc. Pak., 21, 311-320 (1999).

28) Saeed A., Naz R., "Protein Structure-Function Relationship," ed. by Abbasi A., Abid Ali S., BCC\&T Press, University of Karachi, Karachi, 2003, pp. 87-98.

29) Panara F., J. Fish Biol., 51, 275-283 (1997).

30) Fujimoto S., Gotoh H., Ohbayashi T., Yazaki H., Ohara A., Biol. Pharm. Bull., 16, 745-750 (1993).

31) Panara F., Angiolillo A., Fagotti A., Di Rosa I., Pascolini R., Trends Comp. Biochem. Physiol., 1, 675-692 (1993).

32) Ramponi G., Manao G., Camici G., Cappugi G., Ruggiero M., Bottaro B. P., FEBS Lett., 250, 469-473 (1989).

33) Panara F., Biochem. J., 235, 265-268 (1986).

34) Black M. J., Jones M. E., Anal. Biochem., 135, 233-238 (1983).

35) Laemmli U. K., Nature (London), 227, 680-685 (1970).

36) Van Etten R. L., Saini M. S., Clin. Chem., 24, 1525-1530 (1978).

37) Ostanin K., Saeed A., Van Etten R. L., J. Biol. Chem., 26, 8971-8978 (1994).

38) Narise S., Insect. Biochem., 14, 473-480 (1984)

39) Igarashi M., Hollander V. P., J. Biol. Chem., 243, 6084-6089 (1968).

40) Filburn C. R., Arch. Biochem. Biophys., 159, 683-693 (1973).

41) Helwig J. J., Farooqui A. A., Bollack C., Mandel P., Biochem. J., 175, $321-329$ (1978).

42) Ramponi G., Adv. Prot. Phosphatases, 8, 1-25 (1994).

43) Tanizaki M. M., Bittencourt H. M. S., Chaimovich H., Biochim. Biophys. Acta, 485, 116-123 (1977).

44) Cirri P., Caselli A., Manao G., Camici G., Polidori R., Cappugi G., Ramponi G., Biochim. Biophys. Acta, 1243, 129-135 (1995).

45) Ramponi G., Stefani M., Biochim. Biophys. Acta, 1341, 137-156 (1997).

46) Di Pietro D. L., Zengerle F. S., J. Biol. Chem., 242, 3391-3396 (1967).

47) Bittencourt H. M. S., Chaimovich H., Biochim. Biophys. Acta, 438, $153-158$ (1976)

48) Naz R., Saeed A., Protein J., 25, 135-146 (2006).

49) Dissing J., Dahl O., Svensmark O., Biochim. Biophys. Acta, 569, 159-176 (1979).

50) Szalewicz A., Grabska T., Kubicz A., Comp. Biochem. Physiol., 117B, 293-298 (1997). 